\title{
Production of Animal Feed Concentrates From Sour Sop and Pineapple Peels Using Solid State Fermentation
}

\author{
Dr Egwim, Evans C \\ Product Development and Industrial Process Consultant. \\ Biochemistry Department, Federal University of Technology, PMB 65, Minna, \\ Niger State, Nigeria. $+\underline{234} 7065809474$
}

\begin{abstract}
Animal feed concentrates were produced from Soursop (Annona muricata) and Pineapple (Ananas comosus) peels using Aspergillus niger and Aspergillus flavus in a solid state fermentation process. Soursop, pineapple and mixture of soursop and pineapple peels were inoculated with these isolates and incubated for 144hours. The result showed decrease in cellulose and increase in sugars after 144 hours of fermentation. The range in the decrease in cellulose was observed to be between 69 and $86 \%$ while increase in sugars ranged from 219 to $335 \%$. Crude protein levels also increased in the peels considerably after 144 hours of incubation with the highest percentage observed in soursop (48\%) This reveals that these fungi digested the non polysaccharide in soursop and pineapple peels converting them to soluble sugars with significant increase in the protein. Thus, fermentation increase nutritional value of pineapple and soursop making them digestible in animals, hence it can be used as concentrates in formulating animal feeds.
\end{abstract}

KEY WORDS: Nutritional values, Soursop Peels, Pineeapple Peels, Solid State Fermentation, Crude Protein

\section{INTRODUCTION}

Soursop and pineapple peels are abundant and low cost agricultural waste residues. It is easily available in large quantities. They are often discarded after consuming the edible portion of the fruit. Pineapple peel for instance, is a by-product resulting from the processing of pineapple into slices and represents about $10 \% \mathrm{w} / \mathrm{w}$ of the weight of the original fruit (Kareem, et al 2009). It is necessary to explore its industrial reutilization. Agricultural wastes are renewable resource of great variety of biotechnological potential. In recent years waste likes bagasse, rice straw, rice hulls, fruit wastes and starch residues has been used as substrates for growing microbes. These bulk materials are economically useful to control the pollution problems and eliminate the waste disposal problem (Dhanasekeran, 2011). Cellulose, present in most agrowastes, is a potentially valuable source of fiber, fuel and feeds. Much of the cellulose in nature exists as waste material from agriculture industry in the form of husk, stalks, stems and peels, to utilize these waste products and to develop cheaper method for production of cellulase enzyme for enzymatic degradation the production, optimization and purification of bacterial cellulase by solid state bioprocessing of agro biomass has been described (Ajay et al, 2012). Investigations into the ability of microbes to degrade native and modified cellulose revealed that only a few fungi possess the ability to degrade native cellulose while majority of microbes are capable of degrading modified cellulose (Akinyele and Agbro, 2007).

The development of fermentation technologies has been lost in the mist of history and has been regarded as one of the oldest methods of food processing as well as preservation for decades and virtually every culture has it as part of its diets (Viljeon and Heard, 1999). Solid-state fermentations refer to the cultivation of microorganisms in a low-water-activity environment on a non-soluble materials acting as both nutrient source and physical support (Pandey, 2003). Fermentation increases the nutrient contents of food through the biosynthesis of vitamins, essential amino-acids and proteins. It improves protein quality and fiber digestibility. It also enhances the availability of micro nutrient to organisms for utilization and aids in the degradation of anti-nutritional factors. The bioconversion of agricultural and industrial wastes to chemical feedstock using solid state fermentation, has led to extensive studies on cellulolytic enzymes produced by fungi and bacteria (Achinewhu et al., 1998). In spite of the toxic components, coffee husk and pulp are very rich in organic components and has been used as substrates in bioprocesses to produce enzymes, aroma compounds, plant hormones, edible mushrooms and feeds (Soccol, 2001).

Glucose from the hydrolysis of cellulose can be easily fermented into useful products such as ethanol, lactic acid, single cell protein and other value added products such as animal feeds. Anaerobic digestion takes place and the digested slurry may find further application as animal, poultry and fish feeds (Chandra et al., 2009). 
The feed produced via this method is dry, more hygienic does not smell while the dried end products are easily applied in compounding animal feeds. The decomposition of protein present in the feedstock is also high thus, the quality of the feed does not decrease as amino acids do not get decomposed due to the short term process, also trypsin and urease inhibitors which affect the quality of the feedstock are neutralized as fermentation progresses. Digestion becomes easier as starch gets neutralized and as the plant cells (cellulosic products) split into smaller pieces by fragmentation and grinding. The walls of the fat cells are also broken up so that the fat can be released, in this way the calorific value of the product increases. Optimization of media composition is a vital tool to an efficient cell growth and improved secretion of various enzymes that help in degradation. Carbon and nitrogen sources including inorganic salts mainly influence the secretion of ligninolytic enzyme by white rot fungi. The microbial consortium of those microbes improved the quality of cassava tuber skin waste use $n$ the production of fish feeds. These wastes can be harnessed into useful product by using solid state fermentation. This study is channeled towards degradative effect of Aspergillus niger and Aspergillus flavus on the wastes as it affects changes in cellulose, sugars and protein levels in sour sop and pineapple peels and in a mixture of both peels to produce animal feed concentrates. The major criteria for substrate selection are the availability, cost, carbohydrate content, and biodegradability (Kapdan and Kargi 2006).The specific aim of this study is to produce feed concentrate from soursop and pineapple peels so as to meet the nutritional need of animals.

\section{MATERIALS AND METHODS MICROORGANISMS}

The isolates, A. niger and A. flavus were obtained from the Department of Microbiology, Federal university of Technology, Minna, Nigeria. Each isolate was sub cultured on Selective Dextrose Agar (SDA) in a petri dish. The SDA was already acidified with chloramphenicol to prevent contamination by bacteria. The sub cultured isolates were then incubated at $25-28^{\circ} \mathrm{C}$ for 7 days.

\section{SUBSTRATE}

The sour sop and pineapple peels were obtained from a local source. The peels were dried in an oven at $70^{\circ} \mathrm{C}$, powdered and sieved to an average size of 1 to $5 \mathrm{~mm}$.

\section{SOLID STATE FERMENTATION}

$30 \mathrm{~g}$ of dry peel was moistened with $30 \mathrm{ml}$ distilled water in $250-\mathrm{ml}$ Erlenmeyer flasks were autoclaved at $121^{\circ} \mathrm{C}$ for $40 \mathrm{~min}$. One flask containing sour sop was inoculated with $1 \mathrm{ml}$ spore suspension (109 spores/ml) and incubated at $30^{\circ} \mathrm{C}$ for $144 \mathrm{~h} \mathrm{Two} \mathrm{other} \mathrm{flasks} \mathrm{containing} \mathrm{pineapple} \mathrm{and} \mathrm{mixture} \mathrm{of} \mathrm{the} \mathrm{peels} \mathrm{respectively,} \mathrm{were}$ also inoculated with the spores. During the process, the sample was withdrawn at regular intervals (48, 96 and 144h) to determine cellulose, glucose and protein levels. Control was also set up for each sample.

\section{ANALYTICAL METHODS}

Cellulose was analyzed using Updegroff method (1969). Sugars were estimated with 3,5-dinitrosalicylic acid (DNS), using glucose as standard (Miller, 1972) and Protein by the Kjeldahl method (AOAC, 1990).

\section{RESULTS AND DISCUSSION EFFECT OF SOLID STATE FERMENTATION ON CELLULOSE DEGRADATION}

After $148 \mathrm{~h}$ of fermentation, the levels of cellulose in the feed decreased in the substrates (Fig. 1). The range of decrease was between 69 and $86 \%$. Reduction in cellulose levels were more in the treated wastes compared to the untreated. This observation is in agreement with reports by Akinyele and Agbro, (2007), Ofuya and Nwanjiuba (1990), Iyayi and Losel (2001) and Iyayi and Aderolu (2003). The authors reported that over 35\% of the original cellulose content of the substrate was lost during the solid state fermentation. The fungi have the ability to produce enzymes that degrade cellulose as they grow on the substrate. These enzymes degrade the polysaccharides in the starch to soluble sugars within $148 \mathrm{~h}$ of fermentation. A period of seven days is the optimum time for breakdown of non starch polysaccharides in plantain peels using A. niger and A. flavus as against 14 days, reported by Iyayi and Losel (2001), Iyayi and Aderolu (2003) and Iyayi (2004) for agroindustrial by products such as maize offal, wheat offal, corn bran, brewer's dried grains, rice bran and palm kernel meal. 


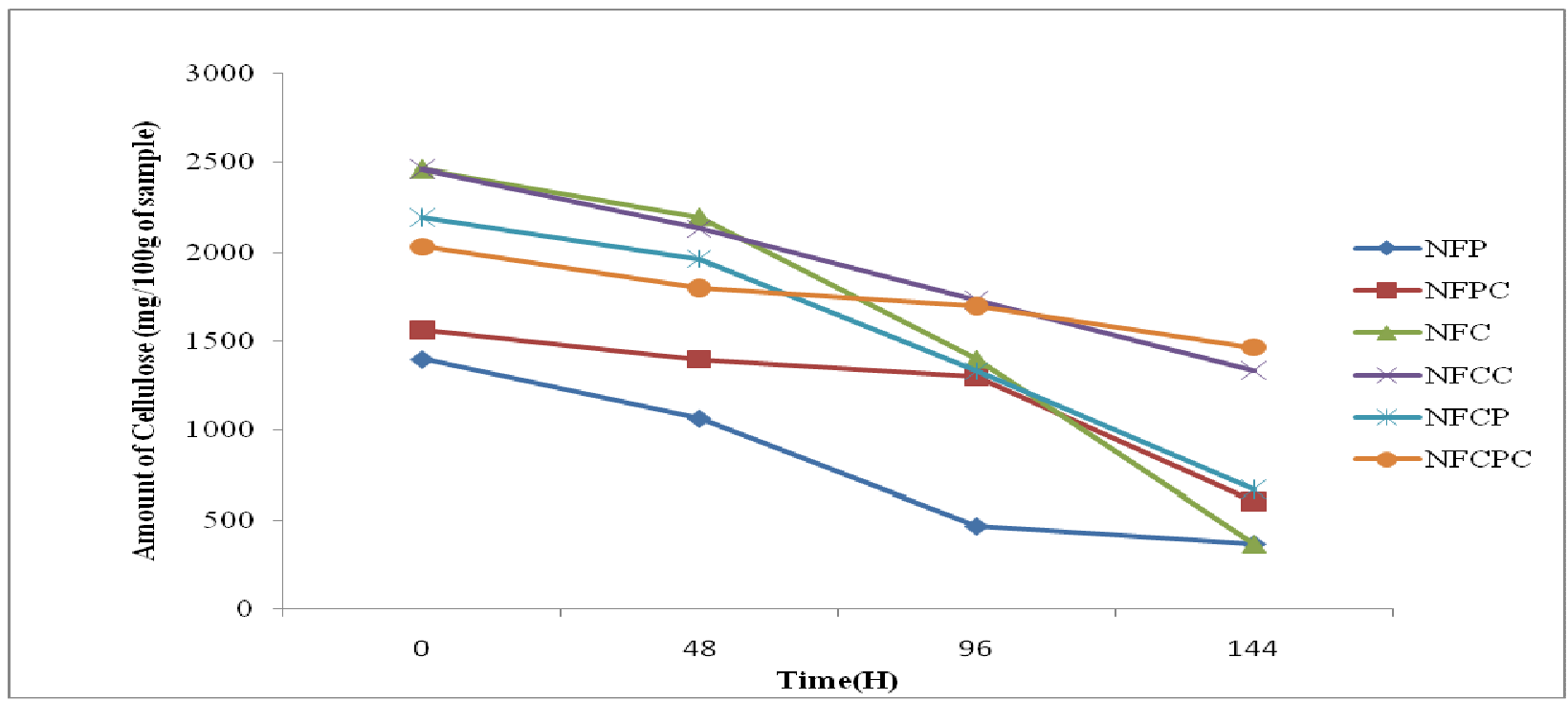

Fig. 1 Changes in Cellulose Levels in Sour Sop And Pineapple Peels In 48-148h.

(N-A.niger, F-A.flavus, P-pineapple, C-soursop, CP- Soursop and Pineapple, PC-P.control, CC-C.control, CPCCP.control).

\section{EFFECT OF SOLID STATE FERMENTATION ON SUGAR YIELD}

Result of changes in sugar level is presented in Fig. 2. Increase in sugars ranged from 219 to $335 \%$ with the highest yield observed in soursop fermented with the mixture of the isolates. The decrease in cellulose due to activities of cellulosic enzymes influenced the sugar production.

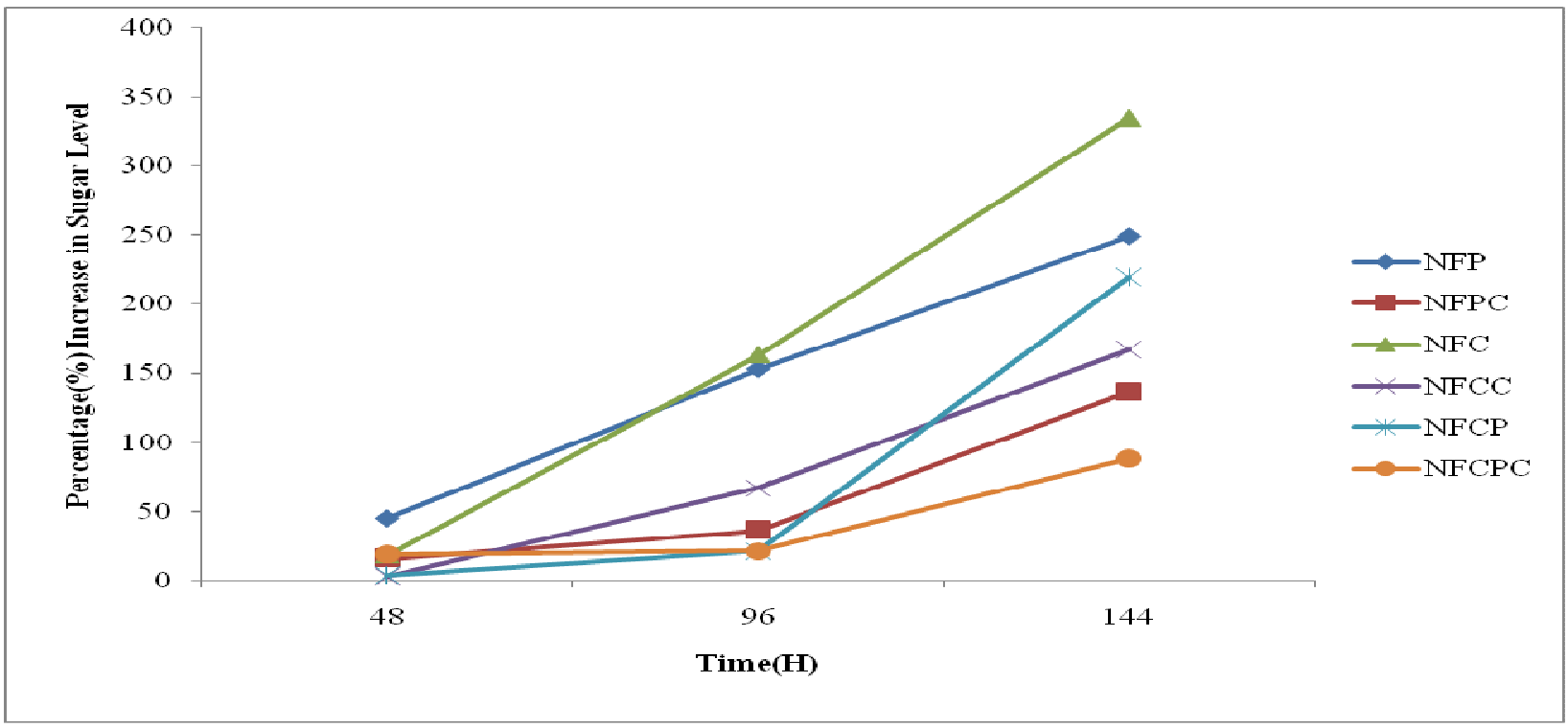

Fig 2. Changes In Cellulose Level Sor Sop And Pineapple Peels in 48-144h.

\section{EFFECT OF SOLID STATE FERMENTATION ON PROTEIN YIELD}

The level of protein progressively increased (Fig 3). The highest percentage increase in protein level (48\%) in sour sop after $148 \mathrm{~h}$ of fermentation was obtained with a mixture of A. niger and A. flavus. The increase observed in the protein levels is as a result of the bioconversion of sugar into proteins (Iyayi, 2004). Akinyele and Agbro (2007) reported highest percentage increase in protein level (34\%) in Unripe Plantain Peels and Ripe Plantain Peels after 7 days of fermentation with A. niger. Monocultures of coffee pulp fermented with fungi, protein content was increased by 15.8 to $22.5 \%$ (Parani and Eyini, 2012). 
Crude protein content was positively correlated with biomass produced by the fungi in substrates. Increased protein in the fermentation process associated with the growth of microbes in the substrate.

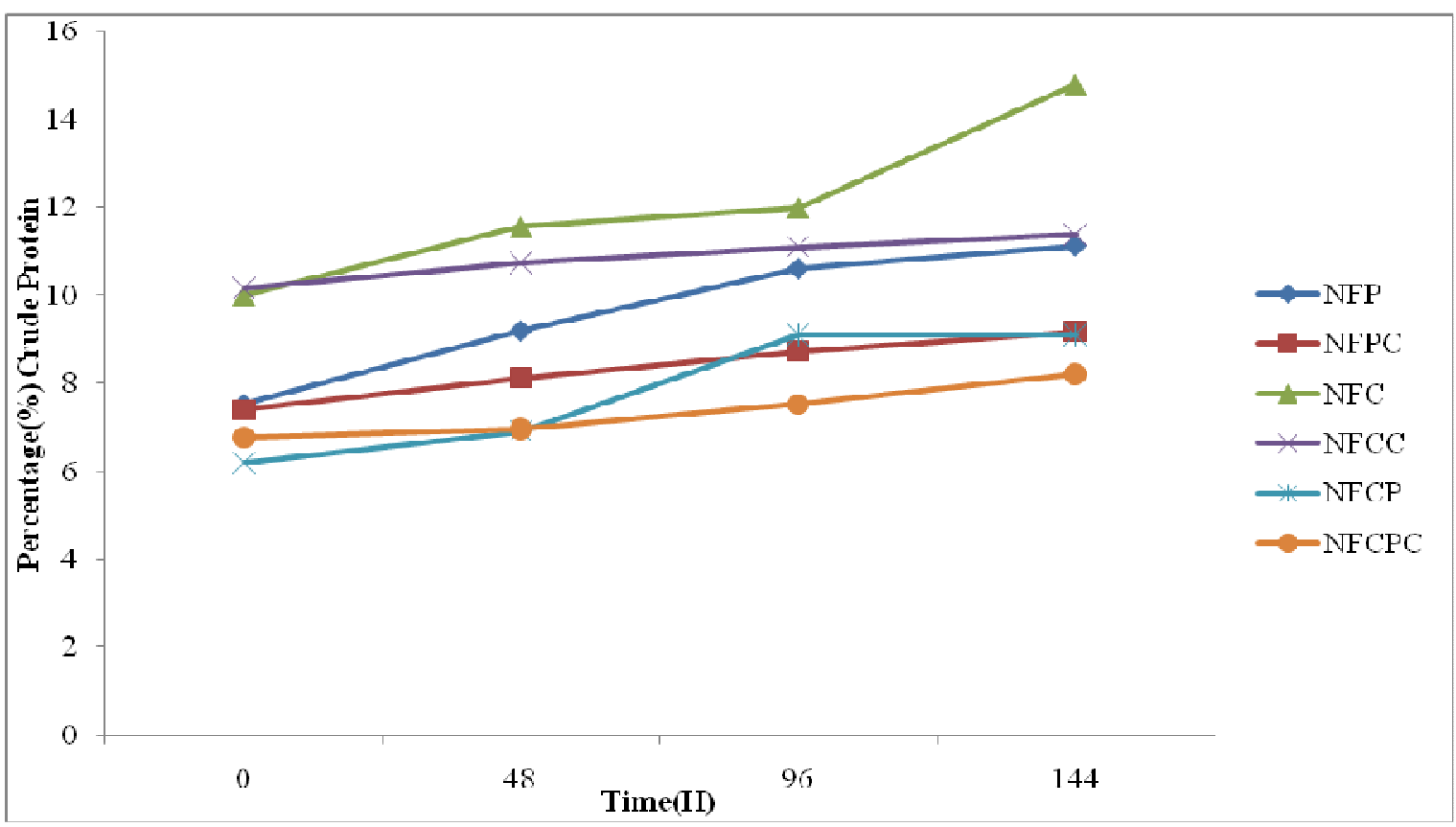

Fig 3. Changes In Protein levels in The Peels In 48-144h.

This investigation has demonstrated that fungal biotechnology is an effective tool for the enhancement of the nutritive values of agro industrial wastes. These fungi degraded the polysaccharide content of the peels, converting them to soluble sugars with significant increase in protein. These biodegradable agro wastes can thus be incorporated into the production of animal feed reducing the use of corn in the diet of animals.

The carbohydrate content of the peels is high and when broken down, constitutes a good medium for fungal growth. The single cell protein synthesized by these isolates increased the crude protein level in the peels. Therefore, the biological treatment using fungi should be employed on a large scale to further increase the nutritive values of these wastes so as to be able to include them in the diet of live stocks. The feed concentrate produced maybe dried to constant weight and stored in air tight condition for subsequent usage.

\section{References}

Achinewhu, S.C. (1998). Nuts and Seeds. In: Nutritional Quality of Plants Food. Osagie, A.U. and O.U. Eka (Eds.).

Ambik Press, Post Harvest Research United University Benin, Nigeria, 134-159. ISBN: 978-2120-02-2.

Ajay, K.S., Abhas, K.M., Harison, M., Yashab, K. S., \& Kumar, M. (2012). Production, optimization and purification of bacterial cellulase by solid state bioprocessing of agro biomass. Research Journal of Pharmaceutical, Biological and Chemical Sciences. 3(2): 977-989.

Akinyele, J., \& Agbro, O (2007). Increasing the Nutritional Value of Plantain Wastes by the Activities of Fungi Using the Solid State Fermentation Technique . Research Journal of Microbiology, 2:117-124.

AOAC (1990). Official Methods of Analysis. Association of Official Analytical Chemists, Washington, DC. USA, pp:69-88.

Chandra, M., Kalra, A., Sangwan, N.S., Gaurav, S.S., Darokar, M.P., Sangwan, R.S., (2009). Development of a mutant of Trichoderma citrinoviride for enhanced production of cellulases. Bioresour. Technol. 100: 16591662.

Dhanasekeran, L., \& Saha, T. (2011) Panneerselvam: Production of single cell protein from pineapple waste using yeast. Innovative Romanian Food Biotechnology . 8: 26-32.

Iyayi, E.A., (2004). Changes in the cellulose, sugar and crude protein contents of agro-industrial by-products fermented with Aspergillus niger, Aspergillus flavus and Penicillum sp. Afr. J. Biotechnol 186-188.

Iyayi, E.A., \& Losel, D.M. (2001). Changes in the carbohydrate fractions of cassava peels following fungal solid state fermentation. J. Food Technol. Afr., 6: 101-103. 
Iyayi, E.A., \& Aderolu, Z.A. (2003). Enhancement of the feeding value o f some agro-industrial by-products for laying hens after their solid state fermentation with Trichoderma viride. Afr. J. Biotechnol., 3: 182-185.

Kareem, S. O., Akpan, I., \& Alebiowu, O. O. (2009). Production of citric acid by Aspergillus niger using pineapple waste. Malaysian Journal of Microbiology, 6(2):161-165

Kapdan, I.K., \& Kargi, F (2006) Bio-hydrogen production from waste materials. Enzyme Microbial Technol 38:569-582.

Miller, G.L. (1959). Use of dinitrosalicylic as reagent for the determination of reducing sugars. Analytical Chemistry, 31, 426- 428.

Ofuya, C.O,. \& Nwanjuiba, C.J. (1990). Microbial degradation and utilization of cassava peel. World J. Microbiol. Biotechnol., 6: 144-148.

Pandey, A. (2003). Solid-state fermentation. Biochemical Engineering Journal 13: 81-84.

Parani, K., \& Eyini, M (2012) . Biodegradation Of Coffee Pulp Waste By Different Fungal Associations. Bioscience Discovery 3(2): 222 -228.

Soccol, C.R (2001). New potentialities and uses of coffee agro-industrial wastes for production of bioproducts in Brazil. In: International Conference on New Horizons in Biotechnology, 18-21, p.26.

Updegraff, D.M. (1969). Semimicro Determination of Cellulose in Biological Materials. Analytical Biochemistry, 32,420-424.

Viljeon, B.C., \& Heard, G.M.(1999) Saccharomyces cerevisiae In: Encyclopedia of food Microbiology. Academic Press.3: 1918-1925. 